Tropical Journal of Pharmaceutical Research June 2010; 9 (3): 251-256

(C) Pharmacotherapy Group, Faculty of Pharmacy, University of Benin,

Benin City, 300001 Nigeria.

All rights reserved.

Research Article

Available online at http://www.tjpr.org

\title{
Microbial Load of Some Medicinal Plants Sold in Some Local Markets in Abeokuta, Nigeria
}

\author{
MacDonald Idu $^{1^{*}}$, Solomon E Omonigho ${ }^{2}$, Joseph O Erhabor ${ }^{1}$ \\ and Harriet M Efijuemue ${ }^{1}$ \\ ${ }^{1}$ Department of Plant Biology and Biotechnology, ${ }^{2}$ Department of Microbiology, University of Benin, PMB 1154, Benin \\ City.
}

\begin{abstract}
Purpose: To evaluate the microbial load on 17 randomly selected plant samples from 60 ethnobotanically collected medicinal plants from five local markets in Abeokuta, Ogun State, Nigeria.

Method: The pour plate method was used to cultivate serially diluted portions of the medicinal plant samples investigated. Enumeration of bacteria was carried out on nutrient agar (NA) while that of fungi was effected on Sabouraud agar (SA).

Results: The identified microbial isolates include 12 bacterial and 6 fungal genera. The mean heterotrophic bacteria counts of the different herbal samples ranged from $1.3 \times 10^{5} \mathrm{cfu} / \mathrm{g}$ (Cnestis ferruginea) to $6.7 \times 10^{6} \mathrm{cfu} / \mathrm{g}$ (Daniellia oliveri), while total fungal propagule counts ranged from $0.0 \times$ $10^{1} \mathrm{cfu} / \mathrm{g}$ (Terminalia superba, Cola gigantea, Rauwolfia vomitoria, Zingiber officinale and Argemone mexicana) to $7.1 \times 10^{6} \mathrm{cfu} / \mathrm{g}$ (Nesogordonia papaverifera). The synopsis and frequency (prevalence rate) of microbial species isolation showed that Bacillus spp. (82.4\%) and Mucor spp. (47.1\%) had the highest prevalence rates among bacteria and fungi, respectively.

Conclusion: The findings from this study emphasized the need for constant quality assessment of herbal drugs on sale in order to ensure the production of therapeutic products suitable for human consumption.
\end{abstract}

Keywords: Microbial load; Medicinal plants; Local markets; Abeokuta; Nigeria 


\section{INTRODUCTION}

In the past, medicinal plants was the first line of treatment known to man and traditional medicinal practice remain an important part of the primary healthcare delivery system in most of the developing world [1]. According to a World Health Organization (WHO) survey, about $70-80 \%$ of the world's populations, particularly in the developing countries, rely on non-conventional medicines, mainly from herbal sources, for their primary healthcare [2].

Generally, plants constitute a major source of orthodox medicines and the presence of plant secondary metabolites has been attributed for most plants' therapeutic activities $[3,4]$. Phytomedicines have shown great promises in the treatment of intractable infectious diseases [5]. The local uses of plants and their products in healthcare are much higher in those areas with little or no access to modern healthcare services [6].

The global and national markets for medicinal herbs have been growing rapidly and significant economic gains are being realized with global sales of herbal products totalling an estimated US $\$ 60$ million in 2000 [7]. However, the current global market for herbal medicines stands at over US\$62 billion annually [8]. The sale of herbal medicine is expected to reach an annual average growth rate of $6.4 \%$ [9]. Several countries, despite their abundant tropical forests, earn nothing significant from the sector. For example, Nigeria is not on the list of countries that have a stake in the over $\$ 60$ billion generated from herbs globally. It is at the moment generating 0.001 per cent of the revenue from herbs [10]. The local markets in Abeokuta form an integral part of the life of the people. Medicinal plants traders in these markets sell large amounts of plants to indigenes and visitors who seek their help. They mostly sell the plants (barks, roots, stems and leaves) in dried forms.
Again, market surveys are an efficient means of acquiring data on local values and conservation status of indigenous species [11]. An understanding of the market profile, social economic attributes influencing trade, species traded and impact of trade on plant pollution is critical for effective resources management [12]. The safety and quality of raw medicinal plant materials and finished products depend on factors that may be classified as intrinsic (genetic) or extrinsic (environment, collection methods, cultivation, harvest, post harvest processing, transport and storage practice [7].

It is against this backdrop that the microbial loads of some of the ethnobotanically collected plants in Abeokuta, Nigeria were carried out.

\section{EXPERIMENTAL}

\section{Study Area}

The study was carried out in the city of Abeokuta, Ogun State, Nigeria. Abeokuta is located within longitude $3^{0} 2^{1}$ East and Latitude $7^{0} 1^{1}$ North. The markets surveyed were Omida, Itoku, Adatan, Kuto and Lafenwa markets. Abeokuta lies within the tropical rainforest area of Nigeria with a population of about one million people and is surrounded by rocks [13].

\section{Collection and identification of plant samples}

The medicinal plant samples were bought from the five local markets surveyed in Abeokuta and aseptically collected with sterile cloves into sterile bags. The samples were immediately kept in clean, cool and dry baskets.

Most of the plant samples were identified by one of the authors (MI) while the others were identified on the basis of their local names and standard texts $[14,15]$. Voucher specimens of the plants were kept in the Department of Plant Biology and 
Biotechnology Herbarium, University of Benin, Nigeria.

\section{Preparation and sterilization of media and samples}

The media used were nutrient agar (NA) and Sabouraud agar (SA) for enumeration of bacteria and fungi, respectively. They were prepared according to the manufacturer's guide and sterilized in an autoclave at $121^{\circ} \mathrm{C}$ for $15 \mathrm{~min}$. The dried plant samples were ground into fine particles under aseptic conditions in a surface sterilized laboratory bench. The grater was washed, dried and sterilized before use. After grinding, the samples were placed in different sterile universal containers and labelled accordingly.

\section{Microbial analysis of plant samples}

The pour plate method was used to cultivate serially diluted portions of the medicinal plant samples under investigation. Enumeration was carried out on nutrient agar (NA) for bacteria and on Sabouraud agar (SA) for fungi. Triplicate plates of appropriate dilutions were prepared. The NA plates were incubated at $37{ }^{\circ} \mathrm{C}$ for $24-48 \mathrm{~h}$ for bacterial growth while SA plates were incubated at room temperature $\left(28 \pm 2^{0} \mathrm{C}\right)$ for $48-72 \mathrm{~h}$ for fungal growth. The developed microbial colonies were counted and computed as colony forming units per gram (cfu/g) of plant material. The colonies were purified, isolated and stored for morphological and biochemical characterization. These were further identified with to the aid of Bergey's Manual of Determinative Bacteriology [16] for bacteria and Illustrated Genera of Imperfect Fungi [17] for fungi.

\section{Statistical analysis}

The results were expressed as mean values \pm SEM of three replicates of the total heterotrophic bacteria and fungi (cfu/g) contained in each plant sample screened. The data were analysed using Students t-test with the aid of SPSS 10 software package.
The level of significance was set at 0.05 . The prevalence rate of the microbial species was also computed.

\section{RESULTS}

The results of the microbial load of the different plant materials are presented in Tables 1 - 4. No significant difference was recorded in both the bacterial and fungal counts (Tables 1 and 2). The mean heterotrophic bacteria counts of the different herbal samples ranged from $1.3 \times 10^{5} \mathrm{cfu} / \mathrm{g}$ (Cnestis ferruginea) to $6.7 \times 10^{6} \mathrm{cfu} / \mathrm{g}$ (Daniellia oliveri) (Table 1), while Table 2 reveals that the total fungal propagule counts ranged from $0.0 \times 10^{1} \mathrm{cfu} / \mathrm{g}$ (Terminalia superba, Cola gigantea, Rauwolfia vomitoria, Zingiber officinale and Argemone mexicana) to $7.1 \times 10^{6} \quad \mathrm{cfu} / \mathrm{g}$ (Nesogordonia papaverifera). The identified microbial isolates consist of 12 bacterial genera and 6 fungal genera as shown in Tables 3 and 4, respectively. The synopsis and frequency (prevalence rate) of the microbial species isolation showed that Bacillus spp. (82.6\%) and Mucor spp. $(47.1 \%)$ had the highest prevalence rates among bacteria and fungi, respectively. The least frequently isolated bacterial species were Arizoma spp., Diphtheroids, Escherichia coli, Proteus spp., Streptococcus spp. and Pseudomonas aeruginosa with a prevalence rate of $5.9 \%$. The figure was the same for the fungal species (Absidia spp., Rhizopus nigrican and Saccharomyces cerevisiae) with the least prevalence rate.

\section{DISCUSSION}

Samples cultured on nutrient agar (NA) were observed to have a large growth of bacterial species while samples cultured on Sabouraud agar (SA) were observed to give few results as fungal species did not grow on some of the cultured samples, namely, Terminalia superba, Cola gigantea, Zingiber officinale, Argemone mexicana and Rauwolfia vomitoria (Tables 1 and 2). Contamination by microorganisms is 
Table 1: Heterotrophic bacterial counts (mean $\pm S D, n=3$ ) of medicinal plant samples obtained from some open markets in Abeokuta, Nigeria

\begin{tabular}{|c|c|c|c|}
\hline Plant sample & Voucher no. & $\begin{array}{l}\text { Heterotrophic } \\
\text { bacterial count } \\
(\mathrm{cfu} / \mathrm{g})\end{array}$ & Predominant bacterial species isolated \\
\hline $\begin{array}{l}\text { Aristolochia } \\
\text { repens }\end{array}$ & BDHS 160 & $5.4 \times 10^{5} \pm 0.01$ & $\begin{array}{l}\text { Citrobacter spp., Klebsiella aerogenes and } \\
\text { Bacillus subtilis }\end{array}$ \\
\hline $\begin{array}{l}\text { Terminalia } \\
\text { superba }\end{array}$ & BDHS 103 & $2.3 \times 10^{6} \pm 0.01$ & $\begin{array}{l}\text { Bacillus subtilis, klebsiella aerogenes and } \\
\text { Arizoma spp. }\end{array}$ \\
\hline $\begin{array}{l}\text { Angylocalyx } \\
\text { oligophyllus }\end{array}$ & BDHS 139 & $3.5 \times 10^{6} \pm 0.01$ & $\begin{array}{l}\text { Bacillus subtilis, Citrobacter spp and } \\
\text { Staphylococcus epidermidis }\end{array}$ \\
\hline $\begin{array}{l}\text { Theobroma } \\
\text { cacao }\end{array}$ & BDHS 130 & $9.3 \times 10^{5} \pm 0.01$ & $\begin{array}{l}\text { Staphylococcus epidermidis, Citrobacter spp, } \\
\text { Bacillus subtilis and Serratia marcescens }\end{array}$ \\
\hline & BDHS 108 & $6.3 \times 10^{6} \pm 0.03$ & $\begin{array}{l}\text { Pseudomonas aeruginosa, Citrobacter spp, } \\
\text { Bacillus spp. and Staphylococcus epidermidis }\end{array}$ \\
\hline Daniellia oliveri & BDHS 132 & $6.7 \times 10^{6} \pm 0.01$ & $\begin{array}{l}\text { Klebsiella aerogenes and Staphylococcus } \\
\text { aureus }\end{array}$ \\
\hline Ficus capensis & BDHS 146 & $5.0 \times 10^{5} \pm 0.02$ & $\begin{array}{l}\text { Serratia marcescens, Citrobacter spp. and } \\
\text { Staphylococcus epidermidis }\end{array}$ \\
\hline Treculia Africana & BDHS 117 & $1.0 \times 10^{6} \pm 0.01$ & Klebsiella aerogenes \\
\hline Mondia whitei & BDHS 105 & $1.1 \times 10^{6} \pm 0.02$ & $\begin{array}{l}\text { Staphylococcus epidermidis and Bacillus } \\
\text { subtilis }\end{array}$ \\
\hline $\begin{array}{l}\text { Securinega virosa } \\
\text { Euphorbia } \\
\text { lateriflora }\end{array}$ & $\begin{array}{l}\text { BDHS } 112 \\
\text { BDHS } 126\end{array}$ & $\begin{array}{l}4.3 \times 10^{5} \pm 0.02 \\
6.0 \times 10^{5} \pm 0.01\end{array}$ & $\begin{array}{l}\text { Bacillus subtilis and Escherichia coli } \\
\text { Proteus spp., Staphylococcus epidermidis and } \\
\text { Bacillus subtilis }\end{array}$ \\
\hline $\begin{array}{l}\text { Cola gigantean } \\
\text { Rauwolfia } \\
\text { vomitoria }\end{array}$ & $\begin{array}{l}\text { BDHS } 151 \\
\text { BDHS } 149\end{array}$ & $\begin{array}{l}4.5 \times 10^{6} \pm 0.02 \\
3.8 \times 10^{6} \pm 0.01\end{array}$ & $\begin{array}{l}\text { Acinetobacter spp. and Bacillus subtilis } \\
\text { Bacillus subtilis, Pseudomonas aeruginosa and } \\
\text { Streptococcus spp. }\end{array}$ \\
\hline $\begin{array}{l}\text { Cnestis } \\
\text { ferruginea }\end{array}$ & BDHS 123 & $1.3 \times 10^{5} \pm 0.01$ & $\begin{array}{l}\text { Bacillus subtilis, Pseudomonas aeruginosa and } \\
\text { Diphtheriods }\end{array}$ \\
\hline Zingiber officinale & BDHS 110 & $2.0 \times 10^{6} \pm 0.02$ & $\begin{array}{l}\text { Acinetobacter spp., Pseudomonas aeruginosa } \\
\text { and Bacillus subtilis }\end{array}$ \\
\hline $\begin{array}{l}\text { Argemone } \\
\text { Mexicana }\end{array}$ & BDHS 143 & $2.2 \times 10^{6} \pm 0.02$ & $\begin{array}{l}\text { Staphylococcus aureus, Bacillus subtilis and } \\
\text { Pseudomonas aeruginosa }\end{array}$ \\
\hline $\begin{array}{l}\text { Heliotropium } \\
\text { indicum }\end{array}$ & BDHS 138 & $3.0 \times 10^{5} \pm 0.01$ & $\begin{array}{l}\text { Bacillus subtilis and Staphylococcus } \\
\text { epidermidis. }\end{array}$ \\
\hline
\end{tabular}

influenced by the environment, improper handling and storage of medicinal plants. One of the major shortcomings of herbal preparations in developing countries is the unhygienic condition under which they are produced [18]. In the present study, it was observed that herbal remedies were not sterile.

This may be due to lack of proper storage facilities and sales infrastructure within the markets visited, hence the plant materials failed to resist contamination [19]; where dispensing hygiene is not good, contamination may be even worse [20].

Inadvertent contamination by microbial or chemical agents during processing could also caused deterioration, thereby compromising safety and quality, and rendering the medicinal plant material less effective and possibly harmful to the consumer [21]. Spoilage of medicines involve basically, initial or early pioneer invaders of biodegrading microorganisms, which prepare the way for later invaders that biodegrade complex 
nutrient, thus altering the surrounding $\mathrm{pH}$ and increasing moisture content [22]. The presence of lipolytic mould such as
Penicillium sp and Aspergillus niger (Table 4) is of great concern as they have been implicated in food poisoning [23].

Table 2: Total fungal propagule counts (mean $\pm S D, n=3$ ) of medicinal plant materials obtained from some open markets in Abeokuta, Nigeria

\begin{tabular}{|c|c|c|c|}
\hline Plant sample & Voucher no. & $\begin{array}{l}\text { Fungal count } \\
\text { (cfu/g) }\end{array}$ & $\begin{array}{c}\text { Predominant fungal species } \\
\text { isolated }\end{array}$ \\
\hline Aristolochia repens & BDHS 160 & $3.1 \times 10^{6} \pm 0.04$ & $\begin{array}{l}\text { Aspergillus fumigatus and } \\
\text { Absidia spp. }\end{array}$ \\
\hline Terminalia superb & BDHS 103 & NIL & No growth \\
\hline Angylocalyx oligophyllus & BDHS 139 & $7.5 \times 10^{5} \pm 0.03$ & Mucor spp. \\
\hline Theobroma cacao & BDHS 130 & $4.6 \times 10^{6} \pm 0.04$ & $\begin{array}{l}\text { Aspergillus fumigatus and } \\
\text { Penicillium spp. }\end{array}$ \\
\hline Nesogordonia papaverifera & BDHS 108 & $7.1 \times 10^{6} \pm 0.01$ & Aspergillus niger and Mucor spp. \\
\hline Daniellia oliveri & BDHS 132 & $4.7 \times 10^{5} \pm 0.03$ & Aspergillus ochraeous \\
\hline Ficus capensis & BDHS 146 & $5.7 \times 10^{4} \pm 0.01$ & Mucor spp. \\
\hline Treculia Africana & BDHS 117 & $1.7 \times 10^{6} \pm 0.01$ & Saccharomyces cerevisiae \\
\hline Mondia whitei & BDHS 105 & $8.5 \times 10^{5} \pm 0.02$ & Mucor spp. \\
\hline Securinega virosa & BDHS 112 & $7.1 \times 10^{5} \pm 0.02$ & Mucor spp. and Penicillium spp. \\
\hline Euphorbia lateriflora & BDHS 126 & $3.6 \times 10^{6} \pm 0.02$ & Mucor spp. \\
\hline Cola gigantean & BDHS 151 & NIL & No growth \\
\hline Rauvolfia vomitoria & BDHS 149 & NIL & No growth \\
\hline Cnestis ferruginea & BDHS 123 & $3.5 \times 10^{6} \pm 0.01$ & Mucor spp. \\
\hline Zingiber officinale & BDHS 110 & NIL & No growth \\
\hline Argemone Mexicana & BDHS 143 & NIL & No growth \\
\hline Heliotropium indicum & BDHS 138 & $6.0 \times 10^{6} \pm 0.03$ & $\begin{array}{l}\text { Rhizopus nigrican and Mucor } \\
\text { spp. }\end{array}$ \\
\hline
\end{tabular}

Table 3: Synopsis and frequency (prevalence rate) of isolation of bacterial isolates from herbal plant samples obtained from some open markets in Abeokuta, Nigeria

\begin{tabular}{ll}
\hline Bacterial isolate & $\begin{array}{l}\text { Prevalence } \\
\text { rate } \\
\text { of isolation } \\
(\%)\end{array}$ \\
\hline Acinetobacter spp. & 11.77 \\
Arizoma spp. & 5.88 \\
Bacillus subtilis & 82.35 \\
Citrobacter spp. & 29.41 \\
Diphtheriods & 5.88 \\
Escherichia coli & 5.88 \\
Klebsiella aerogenes & 17.65 \\
Proteus spp. & 5.88 \\
Pseudomonas aeruginosa & 29.41 \\
Serratia marcescens & 11.77 \\
Staphylococcus epidermidis & 41.18 \\
Staphylococcus aureus & 11.77 \\
Streptococcus spp. & 5.88 \\
\hline
\end{tabular}

Table 4: Synopsis and frequency (prevalence rate) of isolation of fungi from herbal plant samples obtained from some open markets in Abeokuta, Nigeria.

\begin{tabular}{ll}
\hline Fungal isolates & $\begin{array}{l}\text { Prevalence rate } \\
\text { of isolation (\%) }\end{array}$ \\
\hline Absidia spp & 5.88 \\
Aspergillus fumigatus & 11.77 \\
Aspergillus niger & 11.77 \\
Aspergillus ochraeous & 5.88 \\
Mucor spp. & 47.06 \\
Penicillium spp. & 11.77 \\
Rhizopus nigrican & 5.88 \\
Saccharomyces cerevisiae & 588 \\
\hline
\end{tabular}

\section{CONCLUSION}

The findings from this study reiterate the need for constant quality assessment of herbal materials in the market in order to ensure that medicinal plant materials and products are suitable for human 
consumption. Medicinal plants sold in markets should be placed in clean sterile baskets or suitable hygienic packs. The moisture content of the plant materials should always be maintained at minimal levels to reduce the rate of microbial proliferation.

\section{REFERENCES}

1 Akerele O. Medicinal Plants and primary healthcare :agenda for action. Fitoterapia 1998; 59: 353363.

2 Akerele O.Natures medicinal bounty: don't throw it away. World Health Forum. 1993; 14: 390-395.

3 Neumann RR, Hirsch E. Commercialization of Nontimber Forest Products: Review and Analysis for Research, Indonesia: CIFOR, 2000; $p 176$.

4 Timothy $O$, Idu $M$, Falodun $A$, Oronsaye $F E$. Preliminary Phytochemistry and Antimicrobial Screening of Methanol Extract of Baissea axillaris Hau.Leaf. J Biol Sci 2008; 8: 239-241

5 Firenzuoli F, Gori L. Herbal medicine today: Clinical and research issues. Evidence-Based Compl Alternat Med 2007; 4: 37-40.

6 Saeed $M$, Arshad $M$, Ahmad $E$, Ishaque $M$. Ethnophytotherapies for the treatment of various diseases by the local people of selected areas of N.W.F.P. Pak J Biol Sci 2004; 7: 1104-1108

7 W.H.O. World Health Organisation guidelines on good agricultural and collection practices (GACP) for medicinal plants, 2003; $p 80$

8 Aneesh TP, Hishman M, Sekhar MS, Madhu M, Deepa TV. International market scenario of traditional Indian herbal drugs- Indian declining. Int. J. Green Pharm. 2009; 3 :184190.

9 Innamdar $N$, Edalat $S$, Kotwal VB, Powar S. Herbal drugs in Milieu of modern drugs. Int. J. Green. Pharm. 2008; 2 : 2-8.

10 Ezeoke J. Another neglected goose. Tell special edition 2009 [May 11, 2009];19: 28-31

11 Idu M, Osawaru M, Orhue ES. Medicinal plants sold in some local markets in Benin City, Nigeria. Ethnobotany 2005; 17: 118-122
12 Botha J, Witkowski ETF, Shackleton CM. Market Profiles and Trade in medicinal plants in the lowveld, South Africa. Environ Conserva 2004; 31: 38-46.

13 Ojo DA, Mafiana CF. Seasonal pattern of malaria fever among children in Abeokuta, Ogun State, Southwest Nigeria. Pak J. Soc. Sci. 2005; 3 : 572- 576

14 Odugbemi T, Akinsulire O. Medicinal plants by species names In: Odugbemi, T, Ed, Outlines and pictures of Medicinal Plants from Nigeria. Lagos: University of Lagos Press; 2006. pp 73161

15 Akobundu IO, Agyakwa CW. A Handbook of West African Weeds Ibadan: International Institute of Tropical Agriculture, 1998, p 564

16 Buchanan RE, Gibbons NE. Bergey's Manual of Determinative Bacteriology, 8th ed.Baltimore:Williams and Wilkins Co, 1974; $p$ 1268.

17 Barnete HC, Hunter BB. Illustrated Genera of Imperfect Fungi 4th ed. Minnesota: APS Press, 1998; $p 218$

18 Frazier WC, Westhoff DC. Food Microbiology.London: Mc-Graw Hill Publishing Company Limited, 2003; P 1200.

19 Hanazki N, Tamishoro JY, Leitao- Filho H, Gegossi A. Diversity of Plant Uses in Caicaras Communities from the atlantic forest coast, Brazil. Biodiv Conserv, 2000; 9: 597-615

20 Obuekwe IF, Ogbimi AO. Contamination of drugs by microorganisms. Nig J Microbiol 1998; 12: 1317

21 W.H.O. Good manufacturing practices for pharmaceutical products: Main principles. In: W.H.O. Export Committee on Specifications for Pharmaceutical Preparations 2003; $7^{\text {th }}$ report, $p 85$.

22 Omwuliri FC, Wonang DL. Studies on the combined antibacterial action of ginger (Zingiber officinale L.) and garlic (Allium sativum L.) on some bacteria. Nig J Botany 2005; 18: 224228

23 Bampton, SS. Fusari O. Toxicosis in ducks. Veterinariya, 1963; 43: 54-55. 